\title{
Penentuan Kadar Logam Tembaga pada Perairan dan Sedimen di Limbah Pertambangan Tradisional Desa Perabu Kabupaten Lombok Tengah
}

\author{
${ }^{1}$ Dodiy Firmansyah, ${ }^{2}$ Elly Sustiyani \\ Program Studi Farmasi, Fakultas Kesehatan, Universitas Qamarul Huda Badaruddin (UNIQHBA) \\ Bagu, Jl. H. Badaruddin Desa Bagu, Kecamatan Pringgarata, Kabupaten Lombok Tengah 83362, \\ Indonesia \\ Email : dodiy15firmansyah@gmail.com
}

\begin{abstract}
Prabu's people in central Lombok regency make traditional mining for their livelihood. Coppers are one of the wastes from traditional mining, which is dumped into rivers can pollute the waters used by humans a source of clean water. Heavy metals in biota consumed by humans and transmit various diseases, This research to determination copper compound in waters and sediments. The are two puposes of this reseach: (1) to determine coppers in waters and sediments, and (2) to determine copper compound. There are three steps of this reseach: (1) conducting sampling, (2) pretreatment of sediment samples, (3) determining heavy metal levels with the fraction 1 stepwise extraction method (ELFE), and (4) analyzing copper compound. The result showed that copper compound increasing in locations $B$ and C, contain $0.065 \mathrm{mg} / \mathrm{L}$ and $0.051 \mathrm{mg}$ / L in water and contain $89 \mathrm{mg} / \mathrm{kg}, 85 \mathrm{mg} / \mathrm{kg}$ in sediment
\end{abstract}

Keywords:Metals, Waste, Copper

Abstrak. Sebagian besar masyarakat di Desa Prabu Kecamatan Pujut Kabupaten Lombok tengah menjadikan penambangan tradisional sebagai sumber utama mata pencaharian. Salah satu limbah yang dihasilkan dari pertambangan tradisional tersebut yaitu logam berat tembaga yang dibuang ke sungai dan meresap ke sumur-sumur sekitar dapat mencemari perairan yang digunakan masyarakat sebagai sumber air bersih. Selain itu, logam berat yang masuk ke biota dan dikonsumsi oleh manusia dapat menularkan berbagi penyakit, oleh sebab itu penelitian tentang penentuan jumlah logam berat tembaga di perairan dan sedimen perlu dilakukan. Tujuan penelitian ini adalah (1) mengetahui konsentrasi logam berat tembaga di dalam perairan dan sedimen dan (2) mengetahui kadar logam Tembaga. Langkah-langkah dalam penelitian ini anatar lain (1) melakukan survei lokasi, (2) melakukan pengambilan sampel, (3) menetntukan kadar logam berat dengan metode ektraksi bertahap fraksi 1 (ELFE), dan (4) menganalisa logam tembaga. Hasil dari penelitian tersebut adalah meningkatnya konsentrasi logam $\mathrm{Cu}$ pada lokasi $\mathrm{B}$, dan $\mathrm{C}$ di perairan yakni 0,065 $\mathrm{mg} / \mathrm{L}, 0,051 \mathrm{mg} / \mathrm{L}$ serta pada sedimen yakni $89 \mathrm{mg} / \mathrm{kg}$ dan $85 \mathrm{mg} / \mathrm{kg}$

Kata Kunci: Logam, Limbah, Tembaga

\section{PENDAHULUAN}

Secara geografis, Desa Prabu berbatasan langsung dengan Desa kuta sebelah Timur, Desa Rembitan sebelah Utara, dan Desa Tumpak sebelah Barat. Banyaknya pertambangan tradisional yang ada di Desa Prabu kecamatan pujut kabupaten Lombok tengah yang menggunkan aliran sungai sebagai tempat pembuangan limbah pertambangan tradisional menyebabkan terjadinya pencemaran. Desa Prabu masih dipenuhi hutan dan perbukitan yang dimanfaatkan sebagai lahan untuk melakukan kegaiatan pertambangan tradisional (Valian, 2019). Citra Satelit Desa Prabu dijelaskan Pada Gambar 1.

Gambar 1. Citra Satelit Desa Prabu 
Sumber utama masuknya limbah anorganik di lingkungan perairan adalah dari kegiatan pertambangan tradisional yang dapat menyebabkan penurunan kualitas perairan. Limbah tersebut berupa logam berat yang dapat dimakan oleh biota dan dikosumsi oleh makhluk hidup sehingga pencemaran air oleh logam berat tersebut memiliki dampak buruk bagi kesehatan manusia (Anggi, 2012). Untuk itu diperlukan suatu metode untuk mendeteksi keberadaan logam berat lebih awal sebelum kadarnya melebihi nilai amabang batas yang telah ditentukan oleh kementerian lingkungan hidup. Pada penelitian ini dilakukan metode ekstraksi bertahap fraksi (ELFE).

Logam berat umumnya terikat pada fase yang berbeda-beda di dalam sedimen, sehingga spesiasi logam berat memberikan informasi yang menunjukkan tentang kontaminasi logam yang berbahaya bagi lingkungan yaitu fraksi yang mudah lepas dan mudah dipertukarkan. Logam berat dalam sedimen terdapat dalam titik - titik yang berbeda, oleh sebab itu dimungkinkan untuk melihat migrasi logam berat tersebut pada titik tertentu yang mudah lepas dari sedimen ke badan air (Endang, 2006). Berdasarkan data pendukung maka logam yang dipilih dalam penelitian ini adalah logam Tembaga $(\mathrm{Cu})$ dan sampel yang digunakan adalah limbah pertambagan tradisional (Amin, 2011) Tujuan penelitian ini adalah mengetahui konsentrasi logam berat tembaga di dalam perairan dan sedimen dari limbah pertambangan tradisoonal. Penelitian ini sangat penting untuk memberikan informasi tentang bahaya logam berat tembaga di limbah. Penelitian ini sangat penting untuk memberikan informasi tentang bahaya Logam berat Tembaga di Limbah pertambangan tradisional tersebut sesuai baku mutu yang sudah ditentukan.

\section{METODE}

Penelitian dilakukan di Laboratorium Universitas Qamarul Huda Badaruddin. Penelitian ini merupakan penelitian kuantitatif yang bertujuna menentukan konsentrasi Logam Tembaga pada perairan dan sedimen. Tahapan penelitian ini meliputi pengambilan sampel air dan sedimen dari limbah pertambangan tradisional Desa Prabu Kecamatan Pujut. Pengambilan sampel sedimen dan air dilakukan di perairan pembuangan limbah tradisional di Desa Prabu, Kecamatan Pujut, Kabupaten Lombok Tengah.. Pengambilan sampel sedimen dan air dilakukan di tiga titik berbeda yang masing-masing berjarak 100 meter, pengambilan sampel sedimen dilakukan dengan menggunakan grab sampler sedangkan pengambilan sampel air menggunakan water sampler. Sedimen yang diambil sebanyak 250 gram kemudian dimasukkan kedalam kantong plastik (polybag) yang selanjutnya dimasukkan ke dalam ice box yang berisi blue ice sehingga sampel sedimen suhunya tetap $4^{0} \mathrm{C}$. Sampel air diambil $250 \mathrm{ml}$ pada setiap titik sampling kemudian dimasukkan ke dalam botol polyethylene (PE) dan ditambahkan $\mathrm{HNO}_{3} 2$ -3 tetes.

Pretreatmen sampel sedimen dilakukan dengan cara sampel tersebut dikeringkan dan dihaluskan menggunakan mortar kemudian diayak menggunakan ayakan 150 - 200 mesh, sampel sedimen yang digunakan dalam penelitian ini adalah sampel sedimen yang berada diantara 2 ayakan 150 - 200 mesh. Selanjutnya satu gram sampel akan mengalami perlakuan dengan tahapan ekstraksi (Firmansyah, 2019).

Analisa logam Tembaga $(\mathrm{Cu})$ pada sampel sedimen dari pengambilan sampel di titik $\mathrm{A}, \mathrm{B}$, dan $\mathrm{C}$ dilakukan dengan penambahan amonium asetat $\left(\mathrm{NH}_{4} \mathrm{COO}\right) 1$ $\mathrm{M}$ dan larutan asam asetat $\left(\mathrm{CH}_{3} \mathrm{COOH}\right) 0,11$ M. Larutan standart dan sampel yang sudah mendapat perlakuan pemisahan dilanjutkan dengan pengukuran absorbansi dan konsentrasi alat menggunakan AAS AA6200 (Shimadzu). Uji statistik digunakan untuk memilih metode yang digunakan dalam penentuan konsentrasi $\mathrm{Cu}$ pada sampel sedimen yaitu dengan menggukan pengekstrak ammonium asetat dan asam asetat, untuk membandingkan kedua metode tersebut. 


\section{HASIL DAN PEMBAHASAN}

Penambangan tradisional di Desa Prabu Kecamatan Pujut merupakan salah satu sumber utama pecaharian masyarakat sekitar, terlihat dari wilayah yang dikelilingi oleh bukit (Valian, 2019). Salah satu limbah yang dihasilkan dari pertambangan tradisional tersebut yaitu logam berat tembaga yang dibuang ke sungai dan meresap ke sumursumur sekitar dapat mencemari perairan yang digunakan masyarakat. Penelitian ini dilakukan dengan Pengambilan sampel air dilakukan pada tiga lokasi berbeda yakni pada lokasi pembuangan limbah, sebelum pembuanagn limbah, dan setelah pembuanagan limbah pertambangan tradisional yang masing-masing berjarak 100 meter kemudian dianalisis dengan Instrumen AAS menggunakan metode kurva baku. Berdasarkan penelitian yang dilakukan dihasilkan konsentrasi logam tembaga pada tiga titik berbeda di perairan disajikan pada Gambar 2.

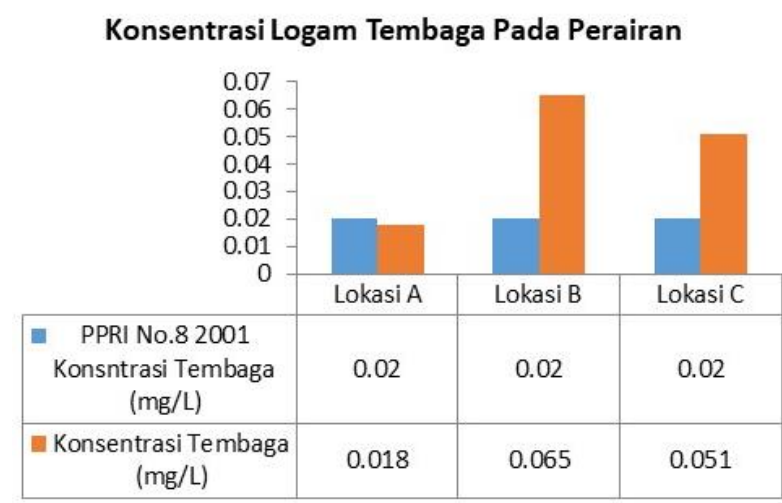

Gambar 2. Konsentrasi logam Tembaga pada perairan

Konsentrasi logam tembaga pada di lokasi pembuangan limbah (lokasi B) dan setelah pembuanagn limbah (lokasi C) melebihi baku mutu yang ditentukan oleh pemerintah yakni $0,065 \mathrm{mg} / \mathrm{L}$ dan $0,051 \mathrm{mg} / \mathrm{L}$, sementara itu pada lokasi sebelum pembuanagn limbah di perairan (titik A) belum melebihi baku mutu yakni $0,018 \mathrm{mg} / \mathrm{L}$ dari $0,02 \mathrm{mg} / \mathrm{L}$, hal tersebut dikarenakan limbah tembaga dari tambang tradisional di Desa Prabu, Kecamatan Pujut belum mengontaminasi perairan. Kandungan logam tembaga pada perairan lebih kecil dibandingkan kadar logam tembaga pada sedimen. Hal ini dikarenakan logam berat yang terlarut dalam air akan berpindah ke dalam sedimen kemudian berikatan dengan materi organik bebas atau materi organik yang melapisi permukaan sedimen (Cahyani, 2012). Konsentrasi logam pada sedimen dapat dilihat pada Gambar 3.

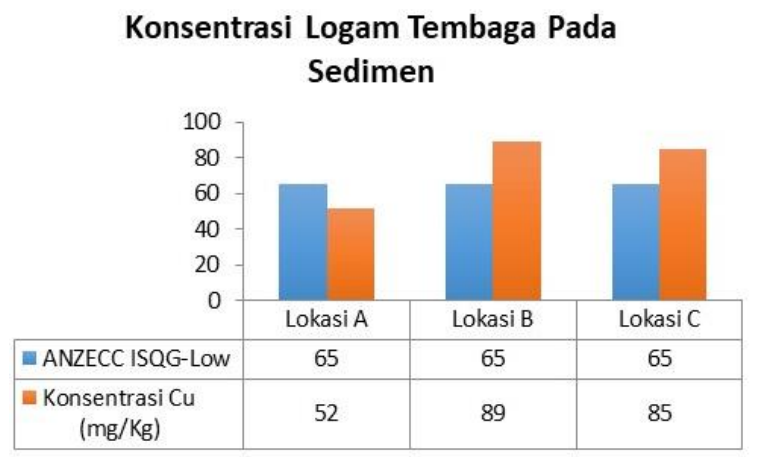

Gambar 3. Konsentrasi logam tembaga pada sedimen

Berdasarkan data diatas Konsentrasi logam $\mathrm{Cu}$ pada sedimen di lokasi $\mathrm{B}$, dan $\mathrm{C}$ melebihi baku mutu yang ditentukan Australian and New Zealand Environment and Conservation Council (ANZECC) yakni $89 \mathrm{mg} / \mathrm{Kg}$ pada lokasi B dan $85 \mathrm{mg} / \mathrm{Kg}$ lokasi C. Sedangkan pada lokasi A belum melebihi baku mutu yang sudah ditentukan yaitu sebesar $52 \mathrm{mg} / \mathrm{Kg}$ yang artinya sedimen pada lokasi tersebut belum terpapar logam Tembaga. Analisis yang dilakukan pada sedimen adalah fraksi 1(ELFE) sedimen, pada faraksi ini karbonat merupakan ikatan yang paling mudah lepas terikat pada bagian luar sedimen. sehingga mudah dilepaskan dari partikel sedimen. Dengan demikian fraksi ini dapat dikaitkan dengan bioavaibilitas perairan, yaitu besarnya logam yang terlepas dari sedimen yang akan dikonsumsi oleh biota (Bahri, 2010). Konsentrasi logam berat $\mathrm{Cu}$ pada lokasi B dan C memiliki konsentrasi yang tinggi dibandingkan pada lokasi A. Banyaknya tanaman yang tumbuh berdekatan disekitar lokasi B dan $\mathrm{C}$ akan mati, tanamantanaman yang mati tersebut merupakan salah satu sumber dari bahan organik pada perairan. Banyaknya bahan organik yang akan meningkatkan nilai kapasitas tukar kation sehingga logam berat $\mathrm{Cu}$ banyak yang terserap kuat di dalam sedimen. 


\section{KESIMPULAN}

Konsentrasi logam berat Tembaga di perairan limbah pertambangan tradisional di Desa Prabu Kecamatan Pujut pada lokasi A, $\mathrm{B}$, dan C yakni 0,018 mg/L, 0,065 mg/L, dan $0,051 \mathrm{mg} / \mathrm{L}$. Konsentrasi Logam tembaga pada lokasi $\mathrm{B}$ dan $\mathrm{C}$ melebihi nilai ambang batas yang ditentukan dengan konsentrasi normal Tembaga di dalam perairan sebesar $0,02 \mathrm{mg} / \mathrm{L}$ serta pada sedimen yakni $89 \mathrm{mg} / \mathrm{kg}$ dan $85 \mathrm{mg} / \mathrm{kg}$ yang artinya perairan dan sedimen pada lokasi tersebut tercemar logam berat Tembaga.

\section{SARAN}

Untuk lebih memahami mobilitas dan ketersedian logam Tembaga serta membedakan proporsi logam berat $\mathrm{Cu}$ yang berasal dari alamiah disarankan melanjutkan metode ekstraksi bertahap ke fraksi 2 yaitu mudah tereduksi, fraksi 3 yaitu fraksi terikat kuat pada mineral, fraksi 4 yaitu fraksi terikat pada baha-bahan organik, dan fraksi 5 yaitu fraksi residual

\section{DAFTAR PUSTAKA}

Amin, B., Afriyani, E., Saputra, M. A. (2011). Distribusi Spasial Logam $\mathrm{Pb}$ dan $\mathrm{Cu}$ Pada Sedimen dan Air Laut Permukaan di Perairan Tanjung Buton Kabupaten Siak Provinsi Riau. Jurnal Teknobiologi, 2(1), 1-8.

Anggi, P. D., Nunik. (2019). Penentuan Kapasitas Adsorpsi Karbon Aktif Sebagai Adsorben Logam Tembaga dalam Limbah Laboratorium. Unesa Journal of Chemistry, 8, (111-115).

Australian and New Zealand Envaironment and Concervation (ANZECC) Interim Sediment quality guidelines. Report for the Envaironmental Research Institute of the Supervising Scientist, Sydey, Australia.

Bahri, W. S. (2010). Spesiasi Logam Berat $\mathrm{Cu}$ dan $\mathrm{Zn}$ dengan Metode Ekstraksi dan Migrasinya dengan "Diffusive Gradient in Thin Film" (DGT) dari
Sedimen Perairan Teluk Jakarta. Disertasi. Program pascasarjana Universitas Indonesia.

Cahyani, M. D., Azizah, R., Yulinto, B. (2012). Studi Kandungan Logam Berat Tembaga $(\mathrm{Cu})$ pada Air, Sedimen, Kerang Darah (Anadara granosa) di Perairan Sungai Sayung dan Sungai Gonjol, Kecamatan Sayung, Kabupaten Demak. Journal Of Marine Research, 1(2), (73-79).

Endang, R. M., Taufik, M. K., Rozak, A. (2006). Distribusi Logam Berat dalam Air dan Sedimen di Perairan Muara Sungai Cisadane. Makara, Sains. 10(1), (35-40).

Firmansyah, D. (2019). Penentuan Kadar Lohgam Tembaga $(\mathrm{Cu})$ Pada Perairan Dan Sedimen Muara Sungai Porong Siduarjo. SainsTech Innovation Journal, 1(1), (1-5).

Hidayah, A. M., Purwanto., Soeprobowati, T. R. (2014). Biokonsentrasi Faktor Logam Berat $\mathrm{Pb}, \mathrm{Cd}, \mathrm{Cr}$ dan $\mathrm{Cu}$ pada Ikan Nila (Oreochromis niloticus Linn) di Karamba Danau Rawa Pening. Biokimia, 16(1), 1-9.

Peraturan Pemerintah Nomor 8 Tahun 2001 tentang Pengendalian Pencemaran Air dan Pengelolaan Kualitas Air.

Valian, Y. A., Dodiy, F., Siti. (2019). Analisa Distribusi Spasial Keanekaragaman Tanaman Obat Berbasis Sistem Informasi Geografis di Desa Prabu Kecamatan Pujut Kabupaten Lombok Tengah. SainsTech Innovation Journal, 2, (6-14). 